University of Nebraska - Lincoln

DigitalCommons@University of Nebraska - Lincoln

Drought Mitigation Center Faculty Publications Drought - National Drought Mitigation Center

2021

\title{
Ranchers' Use of Drought Contingency Plans in Protective Action Decision Making
}

Tonya Haigh

University of Nebraska - Lincoln, thaigh2@unl.edu

Michael Hayes

University of Nebraska-Lincoln, mhayes2@unl.edu

Jolene Smyth

University of Nebraska-Lincoln, jsmyth2@unl.edu

Linda Stalker Prokopy

Purdue University, Iprokopy@purdue.edu

Charles Francis

University of Nebraska - Lincoln, cfrancis2@unl.edu

See next page for additional authors

Follow this and additional works at: https://digitalcommons.unl.edu/droughtfacpub

Part of the Climate Commons, Environmental Indicators and Impact Assessment Commons, Environmental Monitoring Commons, Hydrology Commons, Other Earth Sciences Commons, and the Water Resource Management Commons

Haigh, Tonya; Hayes, Michael; Smyth, Jolene; Prokopy, Linda Stalker; Francis, Charles; and Burbach, Mark, "Ranchers' Use of Drought Contingency Plans in Protective Action Decision Making" (2021). Drought Mitigation Center Faculty Publications. 175.

https://digitalcommons.unl.edu/droughtfacpub/175

This Article is brought to you for free and open access by the Drought -- National Drought Mitigation Center at DigitalCommons@University of Nebraska - Lincoln. It has been accepted for inclusion in Drought Mitigation Center Faculty Publications by an authorized administrator of DigitalCommons@University of Nebraska - Lincoln. 


\section{Authors}

Tonya Haigh, Michael Hayes, Jolene Smyth, Linda Stalker Prokopy, Charles Francis, and Mark Burbach 


\title{
Ranchers' Use of Drought Contingency Plans in Protective Action Decision Making
}

\author{
Tonya Haigh, ${ }^{1}$ Michael Hayes, ${ }^{2}$ Jolene Smyth, ${ }^{3}$ \\ Linda Prokopy, ${ }_{1}^{4}$ Charles Francis, ${ }^{5} \&$ Mark Burbach ${ }^{6}$
}

1 National Drought Mitigation Center, University of Nebraska-Lincoln, Lincoln, NE 68583-0988

2 School of Natural Resources, University of Nebraska-Lincoln, Lincoln, NE 68583-0988

3 Sociology, University of Nebraska-Lincoln, Lincoln, NE 68588-0324

4 Forestry and Natural Resources, Purdue University, West Lafayette, IN 47907

5 Agronomy and Horticulture, University of Nebraska-Lincoln, Kiesselbach Crops Research Laboratory 101, Lincoln, NE 68583-0817

6 Conservation and Survey Division, School of Natural Resources, University of Nebraska-Lincoln, Lincoln, NE 68583-0995

Correspondence - T. Haigh, National Drought Mitigation Center, University of NebraskaLincoln, 802 Hardin Hall, Lincoln, NE 68583-0988, USA; email thaigh2@unl.edu

\begin{abstract}
Drought contingency planning is an increasingly common tool in the ranchers' climate adaptation toolboxes, but its effect on drought response has not yet been evaluated. We use cognitive models of protective action decision making and planning to explore the effects of having a drought plan on the use of drought early warning information and drought response (and timing). Results of a cross-sectional, probability-based survey of livestock producers affected by a 2016 flash-drought are
\end{abstract}

Published in Rangeland Ecology \& Management 74 (2021), pp 50-62.

doi:10.1016/j.rama.2020.09.007

Copyright (c) 2020 The Society for Range Management. Published by Elsevier Inc. Used by permission.

Submitted 14 March 2020; revised 22 July 2020; accepted 16 September 2020. 
used to describe the characteristics of operations with drought plans and provide evidence of whether having a plan predicts drought information use and response. While larger operations are more likely than others to have plans for drought, having a drought plan appears to play a unique role in ranchers' use of information and decision making regardless of operation size. Findings suggest that encouraging the use of drought contingency planning may improve ranchers' adaptive capacity. Increased use of planning may also increase the effectiveness of communicating risk and early warning information, by making such information more actionable by decision makers.

Keywords: Destocking, Drought, Implementation intention, Rangeland, Timing

\section{Introduction}

Rangeland-based livestock producers face increasing challenges to the sustainable management of their ranch operations before, during, and after anomalous climate events such as drought. Years of investment in building the resilience and health of ranch resources can be eroded as a result of mismanagement during a single severe drought event. While this risk is serious, many ranchers find it difficult to mobilize the ranch resources needed to successfully adapt to and cope with drought. Rangeland-based livestock producers often operate under thin profit margins, which often put economics and other management priorities at odds, even for ranchers committed to sustaining their operations through drought (Brunson and Huntsinger 2008; Sayre et al. 2012; Sayre et al. 2013). To support effective ranch drought management, therefore, it is important to identify approaches that help ranchers translate even limited ranch resources into successful response strategies (Marshall and Smajgl 2013; Mortreaux and Barnett 2017).

This study examines drought contingency plans as one such approach to supporting ranchers' decision making and management. A contingency plan addresses how management should be adjusted when conditions occur that are outside of "normal" or "expected" operating ranges. A ranch drought contingency plan typically prescribes forage or livestock management actions to be taken when a specific condition (e.g., deficit of forage production or precipitation received) occurs (Bedell and Ganskopp 1980; Thurow and Taylor 1999; Dunn et al. 2005; Patterson and Richardson 2007; Knutson and Haigh 2013; Kachergis et al. 2014; Briske et al. 2015; Derner et al. 2018). A 
contingency plan is considered a proactive approach to risk management in the sense that it seeks to minimize loss rather than respond to loss (Smit and Skinnner 2002). Drought contingency plans may take a variety of forms, including whether the plan is a written document or a set of guidelines in the manager's mind (Haigh and Knutson 2013). Some ranchers develop plans using scientific data or technology that quantifies the relationship between precipitation amounts throughout the year and forage productivity (Knutson and Haigh 2013). Other ranchers have plans based on traditional knowledge gained over years of monitoring and managing a place (ibid.). Some ranchers complement a contingency plan with mitigation actions that build resilience and flexibility into ranch and financial management. Mitigation actions can improve the options available to the rancher during drought but are not themselves part of the operational definition of a contingency plan.

Increasing in use, up to $60 \%$ of cattle ranchers in Utah and Wyoming have reported using some type of drought contingency planning in their operations (Coppock 2011; Kachergis et al. 2014). However, little research has been done to document the effect of having a contingency plan on ranchers' drought management decisions, given the financial and other resources available in their operations. Some studies have reported that ranchers perceive that their drought management plans improved their outcomes following drought, but the studies did not compare the outcomes of those with and without a plan, or at different resource levels (Coppock 2011; Haigh and Knutson 2013; McClaran et al. 2015). A few studies specifically link having a drought plan with the timing of destocking actions or link the timing of destocking with improved outcomes following drought, but they do not also compare ranchers with and without drought plans (Haigh and Knutson 2013; Haigh et al. 2019; Smart et al. 2019). An empirical examination of the relationship between having a drought plan and decisions made during a specific drought event is necessary to understand the potentials and limitations of the strategy for long-term drought adaptation.

One aspect of the drought contingency plan is of particular interest to climate information providers-the determination of conditions being outside of "normal" or "expected" operating ranges. Many ranchers with drought plans report that monitoring for early 
detection of drought stress is an integral aspect of their plans (Knutson and Haigh 2013). On-farm monitoring is a common strategy, both assessing range forage production and/or installing and using precipitation gauges (ibid.). Climate information providers also encourage the use of scientific climate monitoring information such as that provided by the National Weather Service or the US Drought Monitor (Knutson and Fuchs 2016). These resources are typically referred to as components of drought early warning systems, offering both current condition monitoring and outlooks and forecasts of future conditions (Wilhite and Svoboda 200 0). Scientific data can be valuable to supplement rancher on-farm monitoring effort $s$ by reinforcing what they are seeing, alerting them to the need to pay attention to local conditions, or highlighting local or regional trends.

While drought early warning information may be beneficial to ranch decision making, climate information adoption has been suboptimal (Lemos et al. 2012; Joyce et al. 2013; Kirchhoff et al. 2013; Derner and Augustine 2016; Haigh et al. 2018). Agricultural producers may not trust the accuracy or skill of the information (Haigh et al. 2018) but also may not see the relevance of the information or how it fits in the decisions being made (Cash et al. 2002; Lemos et al. 2012; Kirchhoff et al. 2013; Brasseur and Gallardo 2016) or have sufficient capacity to use the information (Marshall et al. 2011). Research on decision makers' use of climate information has led investigators to focus on improving the relevance and fit of information to decision making, leading to new decision support tools for range management (e.g., Peck et al. 2019). However, to date, there has been little investigation of how having a drought contingency plan might also affect how ranchers use and are influenced by drought monitoring or early warning information. Research is needed to identify the conditions that underlie the value of both the scientific information and the plan itself and to inform efforts to improve the usability of such information for decision making.

Two bodies of social-psychological decision-making theory underlie our research questions regarding the relationships among drought contingency planning, information use, and response actions. The first area of theory aims to describe and predict the ways that an individual's protective action behaviors are triggered by perceived threats in the environment (Grothmann and Patt 2005; Lindell and Perry 2012). 


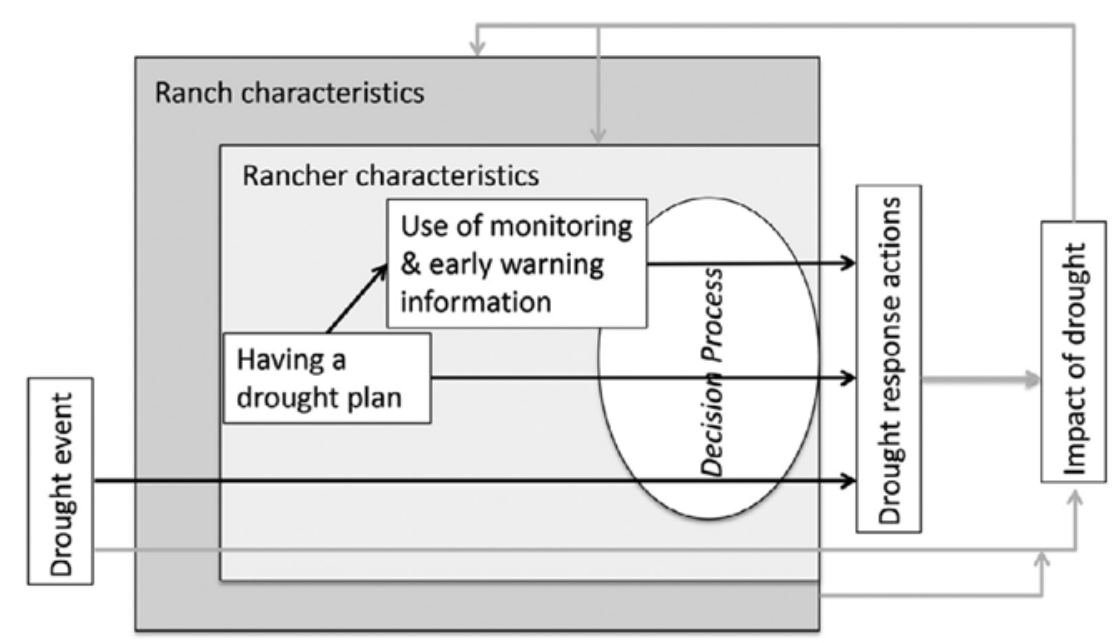

Fig. 1. Conceptual model linking drought contingency plan, use/influence of monitoring and early warning, decision making, and drought response actions. Relationships that are not a focus of this investigation are depicted with gray arrows.

The second body of theory seeks to predict the likelihood of individuals achieving desired behaviors using the concept of implementation intentions, or if-then plans, related to the behavior (Gollwitzer and Sheeran 2006; Webb and Sheeran 2008; Wong et al. 2016).

Before describing the theories that inform our research questions, it is important to note that the social-psychological process of decision making must be understood in the context of the rancher's decisionmaking space. Rancher decision making occurs within the particular situation of his or her own operation, as well as broader social systems related to livestock production practices, land ownership patterns, local and global economics, and culture, as depicted in Fig. 1. This ranch and social context, along with characteristics of the rancher himself or herself, are likely to shape the rancher's perceptions, knowledge, and decision making, including the likelihood of having a drought plan, use of drought early warning information, assessment of risk and management options, and decisions during drought (Kachergis et al. 2014; Roche et al. 2015; Haigh et al. 2019). To understand how the drought contingency plan itself influences decision making and drought response independently of the ranch resources that ranchers have at their disposal, it is important to acknowledge and account for this nested and interrelated decision-making context. 
Within this context, when an individual is faced with a threat such as lack of precipitation, his or her response to the threat may depend on several complex cognitive processes. The Protective Action Decision Model (PADM), for example, depicts a three-stage process of (1) becoming aware of cues to action, (2) weighing potential threats and one's ability to take protective actions, and (3) choosing a behavioral response (Becker et al. 2013; Kuligowski 2013; Terpstra and Lindell 2013; McCaffrey et al. 2018). Many factors influence the process and help to determine how and when the individual will respond. For example, the PADM model shows how situational uncertainty can cause decision makers to cycle repeatedly through the stages of the process rather than making a decision to take protective action (Lindell and Perry 2012). Situational uncertainty may arise from uncertainty about drought development or the ranch's vulnerability to drought, the rancher's level of experience with drought management, or even broader drought policy or market situations. Whatever the source of uncertainty, the longer an individual cycles through the process of seeking information and weighing options before taking action, the more likely it seems that action will be taken reactively rather than proactively. This framework/model shapes our exploration of not only how ranchers respond to drought conditions but also how quickly they respond.

The PADM does not consider the effect of an individual having a contingency plan established before the hazard is encountered. To explore this possible relationship, we turn to the Theory of Implementation Intention's central hypothesis that if a person is motivated to take a particular action, setting a plan that prescribes if-then "rules" for triggering the action improves the likelihood that the action will be taken (Gollwitzer and Sheeran 2006; Webb and Sheeran 2008; Wong et al. 2016). Studies have found that having an if-then plan is associated with the achievement of goals and is associated with more time-efficient action (Aarts et al. 2002; Webb and Sheeran 2007). Ifthen plans have been shown to increase the decision maker's ability to detect specific cues to action, overcome their initial reluctance to take action toward a goal, and shield their goal-oriented behavior from being derailed (Aarts et al. 2002; Gollwitzer and Sheeran 2006; Webb and Sheeran 2007). To date, research on implementation intentions has taken place largely within the context of health behaviors, 
and little has been done to extend these findings to hazard response. Drought contingency plans, like health behavior if-then plans, define specific circumstances and triggers for taking action. We propose that the implementation intentions theory may help explain the effect that having a drought contingency plan has on the rancher's drought decision-making process.

This study addresses the following research questions, informed by the structure of the Protective Action Decision Model, modified by Implementation Intentions Theory (as shown in Fig. 1). First, we examine the degree to which contextual factors affect the likelihood of a rancher having a drought plan.

(1) Are ranchers with a drought plan different from those without, in terms of ranch resources (hectares, income, access to irrigation, or access to a feedlot), or in terms of their own education or experience?

Then, given the contextual factors that may influence having a drought plan, we examine the unique effect of having a drought plan on rancher's use/influence of monitoring and early warning information.

(2) Are ranchers with a drought plan different from those without, in terms of their use and influence of monitoring and early warning information, controlling for the effect of relevant contextual factors?

Finally, given the same contextual factors, we examine the unique effects of both having a drought plan and the use/influence of monitoring and early warning information on drought response and the timing of drought response.

(3) Are ranchers with a drought plan different from those without, in terms of their likelihood of taking action during a specific drought event, controlling for the effect of relevant contextual factors and their use/influence of monitoring and early warning information? 
(4) Are ranchers with a drought plan different from those without, in terms of the time of year they took action during drought, controlling for the effect of relevant contextual factors and their use/influence of monitoring and early warning information?

\section{Methods}

This study examines the use of drought planning by ranchers in the US Great Plains and the outcomes of having a contingency plan during the 2016 drought. The study region includes portions of South Dakota, Nebraska, Colorado, Wyoming, and Montana that were affected by a severe drought event in 2016. The predominant land cover of the US Great Plains region ranges from tall-grass to short-grass prairie but also includes mixed shrub/grassland; cropland used for a variety of crops, including forage, wheat (Triticum aestivum), corn (Zea mays), and sugar beets (Beta vulgaris); and forestland. Livestock production in the region is dominated by cow-calf enterprises that depend on local rangelands, as well as regional supplies of hay and feed. The region is primarily rural, with most counties averaging fewer than 10 people per square mile. ${ }^{1}$ The area is largely dependent on precipitation for agricultural production, with limited areas of irrigated cropland. The study region climate is semiarid, and ranchers in this region are familiar with drought, having recently experienced moderate to extreme drought in the early 2000s, 2012-2013, and 2015. ${ }^{2}$ The most severe drought in recent history was a 2012-2013 event, when much of the region experienced "exceptional drought" levels between the fall of 2012 and the spring of $2013 .{ }^{3}$ During this time, many ranchers were encouraged to develop a drought contingency plan through educational programming and technical support (USDA NRCS 2012).

The study region experienced a quickly developing drought event in 2016. The region entered the spring 2016 season with normal or abnormally dry conditions but experienced a "flash drought" event in late May and June 2016, defined as experiencing a rapid deterioration

\footnotetext{
1 www.census.gov

2 https://droughtatlas.unl.edu

3 https://droughtmonitor.unl.edu
} 
in conditions over a short period of time (Otkin et al. 2018; Pendergrass et al. 2020). The US Drought Monitor depicted abnormal dryness over western South Dakota by the end of May, growth of areas of moderate, severe, and extreme drought by the end of June and large areas of severe and extreme drought by mid-July 2020. On-theground reports of decreased soil moisture and plant stress generally preceded the depiction of drought on the US Drought Monitor but were otherwise consistent, highlighting the role of the US Drought Monitor (USDM) as depicting the emergence of drought conditions over the prior week (looking backwards) rather than being a leading indicator of future drought (Otkin et al. 2018). National Weather Service seasonal and monthly outlooks did not predict the drought (NOAA CPC, 2020), but many ranchers relied upon short-term forecast information throughout the event. Reported impacts of the drought included forest and grassland fires, reductions in grain yields, reduced forage production, water quality and quantity problems, and economic losses characteristic of the severity of drought experienced. ${ }^{4}$

\section{Description of Survey Methods}

We addressed the research questions using the results of a survey of a cross-sectional, probability-based sample of rangeland-based livestock producers who self-identified as the operation's primary decision maker. The sampling frame was a list of landowners with a history of production of forage, wheat, corn, or sugar beets, obtained through a Freedom of Information Request of the USDA Farm Services Agency (FSA). The list contained landowners eligible for FSA programs including conservation programs, FSA farm loans, and emergency and disaster programs (i.e., Livestock .Forage Disaster Program and Livestock Indemnity Program). These lists have been shown to account for $87 \%$ to $90 \%$ of hectares of program crops (Parsons 1996); however, landowners who did not participate in any of these programs at the time, operations listing a trust as the addressee, and individuals who raise livestock but own no land were not represented in the sample. The sample was selected from mailing addresses located within counties included in the study region that experienced at least abnormally dry 


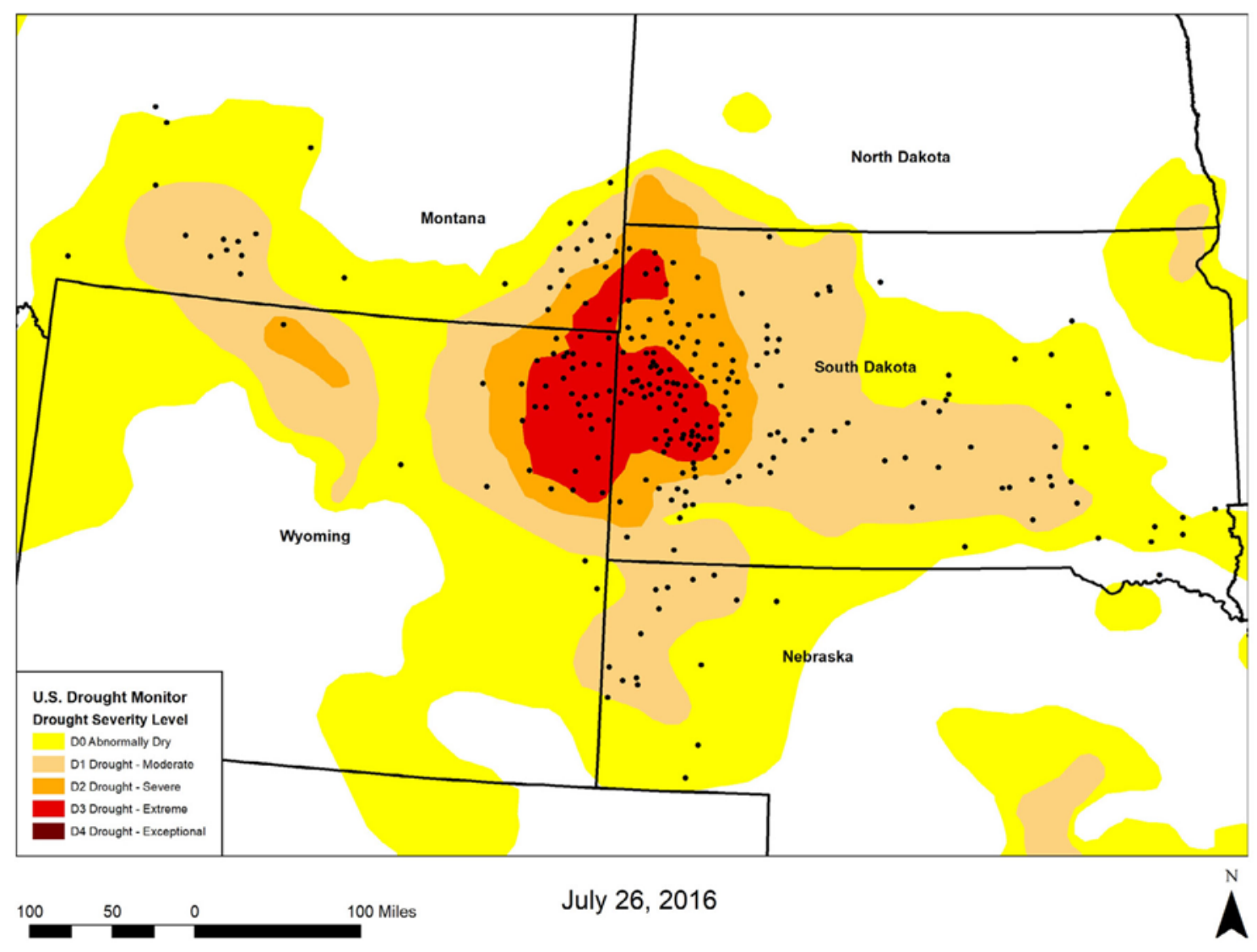

Fig. 2. Black dots overlying the US Drought Monitor for July 26, 2016, represent the approximate locations of survey respondents (randomly distributed within zip codes to protect individual identities) within the US Northern Great Plains region.

conditions (US Drought Monitor Status D0) through midsummer, according to the US Drought Monitor ${ }^{5}$ (Fig. 2).

The sample was stratified on the basis of the location of the landowners' addresses in relation to the 2016 drought's extent and severity, as defined by the US Drought Monitor severity level (Abnormally dry, Moderate drought, Severe drought, Extreme drought, and Exceptional drought) of the landowner's county in mid-July $2016 .{ }^{6}$ In order to ensure representation of landowners experiencing all four levels of drought severity, landowners living in "Abnormally dry" and "Moderate drought" strata (which occurred in more highly populated counties)

5 http://droughtmonitor.unl.edu

6 https://droughtmonitor.unl.edu/Maps/MapArchive.aspx 
were undersampled, while landowners living in "Severe drought" and "Extreme drought" strata (which occurred in less populated counties) were oversampled. No part of the region experienced "Exceptional drought" during this event. As a result, landowners in the sampling frame who lived in "Abnormally dry" areas had a 7\% chance of being included in the sample, those in "Moderate drought" areas had a $20 \%$ chance, those in "Severe drought" had a 70\% chance, and those who lived in "Extreme drought" had a 100\% chance of being included in the sample. Data were weighted to account for unequal probability of selection, and stratification was accounted for in the analysis.

The survey was designed and administered as part of a National Oceanic and Atmospheric Administration Sectoral Applications Research Program (NOAA SARP)-funded project to improve drought early warning capabilities for agriculture in the Missouri River Basin. The survey was administered by the National Drought Mitigation Center via the US Postal Service following the Dillman (1991) method, with a presurvey letter mailed in early November 2016, an initial survey mailing in late November 2016, and a follow-up survey mailing in early January 2017. The presurvey letter and each of the mailed surveys offered respondents the opportunity to take the survey online (Dillman et al. 2014). Of the 2389 surveys that were mailed out, 71 were explicit refusals, 245 were returned but not eligible (either not an agricultural producer or no livestock in operation), 1,819 were not returned and had unknown eligibility, 4 were returned with $<50 \%$ of applicable questions answered, and 250 were returned either partially or completely answered (> 50\% of applicable questions). Using American Association for Public Opinion Research (AAPOR) response rate \#4, the response rate was 18\% (The American Association for Public Opinion Research 2015).

\section{Constructs and Variables}

The survey instrument was developed with the input of content and theory experts and pretested with agricultural extension personnel volunteers. The questionnaire measured drought management actions that producers took, whether or not they had a plan for drought, and the degree to which they used and were influenced by a range of drought monitoring information sources, in addition to demographic 
and operational characteristics. Question wording and answer categories are summarized below and are provided in detail in Table 1.

\section{Having a Drought Plan}

Having a "drought plan" was measured with a question that asked whether the respondent's operation has specific actions that he or she plans to take when drought conditions occur (No, Yes, I don't know). Only $5 \%$ of respondents answered "I don't know" to this question, indicating that respondents understood the concept and knew whether or not they had this type of plan. "I don't know" responses were combined with the "Nos" to create a binary No-Yes variable.

\section{Actions Taken During Drought}

The survey contained two types of measures of drought management actions - variables that measured taking action and variables that measured the timing of taking action. Taking action was operationalized as four separate outcome variables indicating whether or not respondents (1) purchased more hay or feed than usual to supplement existing feed stocks; (2) grazed fall or winter pastures earlier than planned; (3) destocked pastures more than usual through culling, early weaning, ending grazing contracts, sending to feedlot, etc. of any livestock; or (4) culled and sold more breeding animals than usual, because of drought in 2016. These are common drought management strategies documented in the literature (Coppock 2011; Kachergis et al. 2014; Roche 2016; Haigh et al. 2019). The possible responses for each action were "not applicable," "no," and "yes," with "not applicable" responses treated as missing. The timing of taking each action was operationalized as the month respondents reported beginning to take each of the four actions listed above (January-December 2016). Respondents who did not take an action were listed as missing for the associated timing variable.

\section{Information Use/Influence of Drought Early Warning}

Respondents' use and influence of drought early warning information was measured with a survey question asking whether or not they 
Table 1 Variables, question wording, and answer categories.

\section{Variable}

Question wording

Answer categories and codes

\section{Has drought plan}

Does your operation have specific actions that you plan to take when drought conditions occur (e.g., a "drought plan")?

(0) No;

(1) Yes;

(0) I don't know (combined with "No" in analysis)

\section{Drought response actions}

Please indicate whether or not you took each of the following actions on your farm in response to drought conditions in 2016. • Purchase more hay or feed than usual to supplement existing feed stocks $\bullet$ Graze fall or winter pastures earlier than planned $\bullet$ Destock pastures more than usual (through any culling, early weaning, ending grazing contracts, sending to feedlot, etc.) $\bullet$ Cull and sell more breeding animals than usual

(0) No;

(1) Yes;

(Missing)Not applicable

\section{Timing of drought response actions}

If yes, in what month did you begin taking each action? (Same actions as listed above)

(1) January-(12) December

\section{Use/Influence of drought early warning} information

Do you consult any of the following sources for information on drought conditions? If yes, how influential are they to your farming/ ranching management decisions? • On-farm rain gauge or soil moisture sensors $\bullet$ Own assessment of crop range or livestock conditions • National Weather Service • U.S Drought Monitor

(0) Not used;

(1) Used, but not influential;

(2) Used and somewhat influential;

(3) Used and very influential

\section{Land base}

Please indicate the total number of acres you own and rent from others that are range or pasture land.

Write in number (converted to ha)
Financial resources

Please indicate the level of your gross farm/ranch sales in a typical year.

(1) Under $\$ 25,000$;

(2) $\$ 25,000-\$ 49,999$;

(3) $\$ 50,000-\$ 99,999$;

(4) $\$ 100,000-\$ 249,999$;

(5) $\$ 250,000-\$ 499,999$;

(6) $\$ 500,000-\$ 999,999$;

(7) $\$ 1,000,000+$

\section{Experience}

For how many years have you been a primary decision maker for your farm/ranch?

(1) Fewer than 10;

(2) 10-19;

(3) 20-29;

(4)30-39;

(5) 40-49;

(6) 50 or more

\section{Education}

What is the highest level of education that you have completed?

(1) Less than high school;

(2) High school/GED

(3) 2-year college/tech/Associate;

(4) 4-year college (Bachelor's);

(5) Advanced degree (MS, MBA, PhD, etc.)

\section{Range condition}

If you manage range or pasture land, what percent was classified as excellent, good, fair, or poor range condition prior to 2016?

Write in number

\section{Irrigation}

Is any of your pasture/range land irrigated or sub-irrigated?

(0) No;

(1) Yes

\section{Summer drylot/feedlot}

Please indicate whether or not you feed livestock in a feedlot or dry lot during summer growing season.

(0) No;

(1) Yes 
used and were influenced in their management by drought monitoring and early warning resources including: on-farm rain gauges or soil moisture sensors; their own assessment of crop, range, and livestock conditions; the National Weather Service; and the USDM. Response categories included "not used," "used but not influential," "used and somewhat influential," and "used and very influential."

\section{Rancher Characteristics}

Rancher characteristics shown to affect decision making include educational level and experience (Jianjun et al. 2015). Education was measured on a categorical scale, from "some formal education, less than high school" to "advanced degree (MS, MBA, PhD, etc.)." Experience was measured as the number of years the respondent had been the primary decision maker for their farm/ranch, on a categorical scale of "fewer than 10 years" to "50 years or more."

\section{Ranch Characteristics}

Ranch characteristics that may affect ranchers' decision making include the size of the operation, or land base in terms of hectares, and financial resources (Kachergis et al. 2014). The rangeland land base was measured through a survey question asking respondents to write in the total number of acres of all owned and rented rangeland, which was converted to hectares. The log of this total was included in analyses to account for the nonlinear distribution of farm/ranch sizes, with a large number of farms/ranches operating a small amount of land, and a small number of farms/ranches operating large amounts of land (USDA, ERS 2020). Financial resources were also measured as gross farm/ranch sales, measured categorically from "under $\$ 25,000$ " to " $\$ 1,000,000$ or more."

In addition to the ranch's resources, the sensitivity of the ranch to harm may affect the rancher's decision making (Haigh et al. 2019). Three potential sources of drought sensitivity in the operation were included in the analysis: range condition, measured as the percent of range classified as "excellent" before 2016 (0-100\%); whether any pasture/range land is "irrigated or subirrigated" (No/Yes); and whether or not the operation includes a year-round feedlot (No/Yes). 
Finally, the context of the drought event experienced at the ranch's location is likely to have an effect on decision making (Briske et al. 2015; Haigh et al. 2019). Drought severity experienced between October 2015 and June 2016 was included in the analysis as a control variable. We accounted for the drought severity experienced by each respondent in 2016 by linking a common precipitation index to the survey records. We used the Standardized Precipitation Evapotranspiration Index (SPEI) value as a measure of the overall dryness experienced by each survey respondent during the months that drive forage productivity in the region. SPEI values range from positive 3 to negative 3 , with positive values indicating greater than median precipitation and negative values indicating less than median precipitation. We used SPEl values for October 2015-June 2016 to represent key forage production months for the study region (Smart et al. 2007). The 3-mo SPEl was used to depict the balance between precipitation and potential evapotranspiration over the previous $3 \mathrm{mo}$, calculated at weekly intervals, and was calculated as a monthly median value for each respondent's county, as described by Haigh et al. (2019) .

\section{Statistical Analysis}

Data were weighted to account for unequal probability of being sampled, and stratification was accounted for in the analysis using STATA "svy" code (Statacorps 2009). Stata v. 11 was used for all descriptive and inferential statistical analysis (ibid.). Analysis followed a multistep process.

First, we examined the relationship between a rancher having a drought plan and his or her education and experience and between having a drought plan and various characteristics of the ranch operation. These relationships were tested to assess whether those with a drought plan are contextually different from those without a drought plan. The relationships between having a drought plan and the rancher's individual and operation (ranch) characteristics were assessed using the following tests of association. We examined whether there was a significant difference in size (hectares) of rangeland or percent excellent condition rangeland between those with and without a drought plan using an adjusted Wald test to compare group means. We examined the relationship between having a drought plan and 
characteristics measured at the ordinal or categorical levels (i.e., gross sales, education, years of experience, irrigation, feedlot) using a Chisquare test of association. Characteristics of the ranch and rancher that were found to have a relationship with having a drought plan at a significance level of 0.05 were added as control variables to models used to predict ranchers' use of drought early warning information, actions taken during drought, and timing of action.

We examined the relationships between having a drought plan and the use/influence of information, drought response action, and the timing of action using multivariable logistic and ordered logistic models containing relevant control variables described earlier. We examined the use/influence of on-farm monitoring and drought early warning information as a function of having a drought plan, contextual control variables, and drought severity as a control variable. We examined the rancher's drought response actions and the timing of actions as a function of having a drought plan, use/influence of onfarm monitoring and drought early warning information, contextual control variables, and drought severity as a control variable. We included use/influence of the types of drought early warning information associated with having a plan in the drought response models as potential mediators in the relationship between having a drought plan and the rancher's drought response actions and the timing of action. We ran separate predictive models with each of type of drought early warning information that we found to be related to having a drought plan, rather than incorporating all types of information in the same model, due to the small $n$ for each analysis and associated need to limit the number of predictive variables in each.

The type of regression model used depended on the type of dependent variable to be predicted. We examined the effect of having a drought plan on binary dependent (yes/no) variables (i.e., whether or not a specific drought response action was taken) using logistic regression models. We examined the effect of having a drought plan on ordered or scaled categorical outcomes (i.e., use/influence of information, month of taking action) using ordered logistic regressions, or proportional odds models, which do not depend on the outcome category and are useful for determining the general direction of response (Hosmer et al. 2013). In each case, we examined full models, determined whether or not the full model predicted the outcome 
variable better than a null or random model, and determined whether or not having a drought plan contributed significantly to the predictive model. The models with parameters were compared with the null model using a likelihood-ratio test appropriate for nested models, the F-test. An F-test different from the null (probability that $F$ is not 0 ) indicates that the more complex model (inclusive of the drought plan variable) may provide a better fit than the random, null model. If the full model improved prediction over the null model, the importance of having a drought plan to the model was determined by examining the t-value of the variable's coefficient in the model. If the t-value of the coefficient was statistically different from 0 , the variable could be said to contribute significantly to the predictive model. Statistical significance was determined with a 95\% confidence level at an alpha $=0.05$.

Logical skip-patterns in data led to substantial missing data for variables measuring the timing of protective actions. Cases with missing data were eliminated from analysis using casewise deletion. For the methods used in this study, 250 responses were adequate to obtain a power of 0.80 , assuming small-to-medium $(\sim 0.20)$ effect sizes (Cohen 1992). Where skip patterns resulted in a lower $n$ (i.e., the timing of protective actions), the analysis was only powerful enough to detect medium effect sizes (e.g., 0.30 and above) and may have missed smaller effect size relationships.

\section{Results}

\section{Effect of Rancher and Ranch Context on Likelihood of Having a Drought Plan}

Fifty-nine percent of ranchers in this study region reported having an if-then plan for drought, similar to the proportion found by Kachergis et al. (2014) in Wyoming. Rancher and operation characteristics are provided in Table 2 . Ranchers with a drought plan were not different from those without a plan in terms of their levels of education or years of experience and also were not working in different contexts in terms of whether or not they fed livestock in a feedlot or the percent of their rangeland they classified as "excellent" (Table 3). However, ranchers with a drought plan tended to run larger operations in 
Table 2 Characteristics of ranchers and operations: weighted mean or proportion, standard error, and number of observations.

\begin{tabular}{|c|c|c|c|c|}
\hline \multirow{2}{*}{$\begin{array}{l}\text { Variable } \\
\text { Has a plan for drought }\end{array}$} & \multirow[t]{2}{*}{ Category } & roportion & \multirow[t]{2}{*}{$S E$} & \multirow{2}{*}{$\frac{N}{252}$} \\
\hline & & & & \\
\hline & No & 0.34 & 0.05 & \\
\hline & Yes & 0.59 & 0.05 & \\
\hline & $\begin{array}{l}\text { I don't know (combined } \\
\text { with "No" in analysis) }\end{array}$ & 0.05 & 0.02 & \\
\hline & Missing & 0.02 & 0.01 & \\
\hline Land base (range hectares) & & 1118.90 & 145.59 & 232 \\
\hline \multirow[t]{9}{*}{ Financial resources } & & & & 252 \\
\hline & Under $\$ 25,000$ & 0.07 & 0.02 & \\
\hline & $\$ 25,000-\$ 49,999$ & 0.10 & 0.03 & \\
\hline & $\$ 50,000-\$ 99,999$ & 0.18 & 0.04 & \\
\hline & $\$ 100,000-\$ 249,999$ & 0.28 & 0.04 & \\
\hline & $\$ 250,000-\$ 499,999$ & 0.15 & 0.03 & \\
\hline & $\$ 50,0000-\$ 999,999$ & 0.11 & 0.03 & \\
\hline & $\$ 1,000,000+$ & 0.03 & 0.02 & \\
\hline & Missing & 0.09 & 0.03 & \\
\hline \multirow[t]{8}{*}{ Rancher experience (years) } & & & & 252 \\
\hline & Fewer than 10 & 0.08 & 0.02 & \\
\hline & $10-19$ & 0.14 & 0.02 & \\
\hline & $20-29$ & 0.18 & 0.02 & \\
\hline & $30-39$ & 0.23 & 0.03 & \\
\hline & $40-49$ & 0.20 & 0.03 & \\
\hline & 50 or more & 0.13 & 0.02 & \\
\hline & Missing & 0.044 & 0.01 & \\
\hline \multirow[t]{7}{*}{ Rancher education } & & & & 252 \\
\hline & Less than high school & 0.02 & 0.01 & \\
\hline & High school/GED & 0.34 & 0.04 & \\
\hline & 2-yr degree & 0.23 & 0.04 & \\
\hline & 4-yr degree & 0.27 & 0.04 & \\
\hline & Advanced degree & 0.10 & 0.03 & \\
\hline & Missing & 0.04 & 0.02 & \\
\hline \multirow[t]{4}{*}{ Irrigation } & & & & 252 \\
\hline & No & & 0.72 & 0.04 \\
\hline & Yes & & 0.17 & 0.03 \\
\hline & Missing & 0.11 & 0.03 & \\
\hline \multirow[t]{4}{*}{ Summer drylot/feedlot } & & & & 252 \\
\hline & No & 0.71 & 0.04 & \\
\hline & Yes & 0.12 & 0.03 & \\
\hline & Missing & 0.17 & 0.04 & \\
\hline \multicolumn{2}{|c|}{ Range condition (percent excellent condition) } & 29.22 & 3.41 & 209 \\
\hline \multicolumn{2}{|c|}{ SPEl ${ }^{a}$ from October 2015 through June 2016} & -0.10 & 0.01 & 252 \\
\hline
\end{tabular}

a. Standardized Precipitation Evapotranspiration Index. 
Table 3 Comparing the characteristics of groups with and without a drought plan.

\begin{tabular}{lrrrr} 
Variable & Uncorrected chi $^{2}$ & $F$ & Prob. & $n$ \\
\hline Land base (range ha) & & 9.39 & 0.00 & 225 \\
Irrigated pastures & 7.82 & 5.71 & 0.02 & 224 \\
Gross sales & 26.49 & 2.33 & 0.04 & 220 \\
Education & 11.99 & 1.81 & 0.14 & 231 \\
Experience (yr) & 13.74 & 1.29 & 0.27 & 230 \\
Feedlot & 0.08 & 0.03 & 0.85 & 200 \\
Range condition (percent excellent) & 1.24 & 0.27 & 204 \\
\hline
\end{tabular}

Reporting uncorrected Chi-square tables and Adjusted Wald (F Comparison of Means), probability that the groups are not different, and the number of observations used to compare groups.

terms of land base, reported higher gross sales, and were less likely to have irrigated/subirrigated pastures. Land base and gross sales were highly correlated with one another (Spearman Rho $=0.64, P=0.00$ ). For the subsequent analyses, land base and having irrigated pastures were used as control variables. We did not use gross sales as a control variable because of the likelihood that collinearity with land base would make interpretation of the results more difficult.

\section{Effect of Having a Drought Plan on Use/Influence of Drought Early Warning Information}

As reported in Haigh et al. (2019), ranchers were most influenced by their own assessment of conditions in making decisions during drought, with $77 \%$ of ranchers making their own assessments and $50 \%$ saying that their own assessments were "very influential." Over 70\% of ranchers used on-farm rain gauges and/or soil moisture monitors and were evenly split between finding the information "somewhat influential" and "very influential." Over half of ranchers used information from the US Drought Monitor, or from the National Weather Service, but on average, they considered it only "somewhat influential" (Table 4). In the full predictive models, having a drought plan was associated with ranchers' increased use and influence of their own assessments of conditions (Coef. $=1.40, P=0.01$ ) and the National Weather Service (Coef. $=1.06, p=0.01$ ) (Table 5). Having a drought plan was also associated with increased use and influence of on-farm rain gauges 
Table 4 Proportion of producers who use and are somewhat or very influenced by sources of drought early warning information.

Weighted proportion

\begin{tabular}{lll}
\hline Own assessment of crop, range, or livestock conditions & & \\
Not used & 0.20 & 0.04 \\
Used, but not influential & 0.00 & 0.00 \\
Used and somewhat influential & 0.27 & 0.04 \\
Used and very influential & 0.50 & 0.05 \\
Missing & 0.04 & 0.02 \\
On-farm rain gauge or soil moisture sensors & & 0.04 \\
Not used & 0.27 & 0.02 \\
Used, but not influential & 0.06 & 0.04 \\
Used and somewhat influential & 0.33 & 0.05 \\
Used and very influential & 0.32 & 0.01 \\
Missing & 0.03 & 0.05 \\
National Weather Service & & 0.02 \\
Not used & 0.32 & 0.05 \\
Used, but not influential & 0.03 & 0.04 \\
Used and somewhat influential & 0.47 & 0.01 \\
Used and very influential & 0.16 & \\
Missing & 0.02 & 0.05 \\
US Drought Monitor & & 0.03 \\
Not used & 0.43 & 0.04 \\
Used, but not influential & 0.09 & 0.04 \\
Used and somewhat influential & 0.30 & 0.15 \\
Used and very influential & 0.02 & \\
Missing & & \\
\hline Reporting weighted proportions & \\
\hline
\end{tabular}

Reporting weighted proportions and standard errors. $N=252$ for all, including missing cases.

(Coef. $=0.99, P=0.04)$, though the full models did not improve prediction over the null random model. Having a drought plan was not associated with use/influence of the US Drought Monitor. These results suggest that having a drought plan does increase the use and influence of on-farm assessment of conditions and some, but not all, types of drought early warning information.

\section{Effect of Having a Drought Plan on Drought Response Actions Taken}

Forty-five percent of ranchers responded to drought conditions in 2016 by grazing fall/winter pastures earlier than planned (Table 6). Forty-four percent destocked pastures through some means more 
Table 5 Ordered logistic and linear regression models predicting the use/influence of individual types of early warning information.

$$
\text { Coef. Std. Err. } \quad T \quad P>t \quad \text { Model Stats. }
$$

On-farm rain gauge or soil moisture sensors

$\begin{array}{lrrrrrr}\text { Irrigation } & -0.50 & 0.58 & -0.86 & 0.39 & \mathrm{n} & 199 \\ \text { Land Base } & -0.01 & 0.14 & -0.06 & 0.95 & \mathrm{~F}(4,192) & 1.61 \\ \text { Drought Severity } & -0.08 & 0.80 & -0.10 & 0.92 & \text { Prob > F } & 0.17 \\ \text { Drought Plan } & 0.99 & 0.49 & 2.02 & 0.04 & & \end{array}$

Own assessment of crop, range, or livestock conditions

$\begin{array}{lrrrrrr}\text { Irrigation } & -0.29 & 0.46 & -0.63 & 0.53 & \mathrm{~N} & 198 \\ \text { Land Base } & -0.05 & 0.15 & -0.34 & 0.73 & \mathrm{~F}(4,191) & 5.90 \\ \text { Drought Severity } & -2.09 & 0.72 & -2.91 & 0.00 & \text { Prob > F } & 0.00 \\ \text { Drought Plan } & 1.40 & 0.49 & 2.87 & 0.01 & & \end{array}$

National Weather Service

$\begin{array}{lrrrrrr}\text { Irrigation } & -0.92 & 0.63 & -1.46 & & 0.15 \mathrm{n} \mathrm{200} & \\ \text { Land Base } & 0.28 & 0.15 & 1.93 & 0.06 & \mathrm{~F}(4,193) & 4.51 \\ \text { Drought Severity } & 0.08 & 0.88 & 0.09 & 0.93 & \text { Prob > F } & 0.00 \\ \text { Drought Plan } & 1.06 & 0.39 & 2.69 & 0.01 & & \\ \text { US Drought Monitor } & & & & & & \\ \text { Irrigation } & -0.75 & 0.56 & -1.35 & 0.18 & \mathrm{n} & 198 \\ \text { Land Base } & 0.28 & 0.14 & 2.01 & 0.05 & \mathrm{~F}(4,191) & 2.31 \\ \text { Drought Severity } & 0.57 & 0.82 & 0.69 & 0.49 & \text { Prob > F } & 0.06 \\ \text { Drought Plan } & 0.49 & 0.45 & 1.07 & 0.28 & & \end{array}$

Coefficients and measures of significance $(t, P>t)$ are provided for each model variable. Tests of overall fit (F-statistic, Prob $>F$ ) are provided for each model, as well as the number of observations used in the model.

than usual, though fewer (29\%) culled their breeding herds. Thirty-six percent purchased more supplemental hay or feed.

We found that having a plan increased the likelihood of taking some actions but not others. Ranchers with drought plans were more likely than others to destock through some means due to drought conditions in 2016, controlling for operational factors, drought severity, and any type of use of drought early warning information (Table 7). However, ranchers with a drought plan were no more or less likely than others to purchase supplemental feed, early graze fall/ winter pastures, or cull their breeding herds because of the drought. These results are consistent with past descriptive research finding that drought contingency plans tend to be primarily focused on destocking actions (Knutson and Haigh 2013). 
Table 6 Proportion of producers taking drought response actions, and the month they began acting.

\begin{tabular}{|c|c|c|}
\hline & Weighted proportion & $S E$ \\
\hline \multicolumn{3}{|c|}{ Purchase more hay or feed than usual to supplement existing feed stocks } \\
\hline No & 0.49 & 0.05 \\
\hline Yes & 0.36 & 0.04 \\
\hline Missing or Not Applicable & 0.15 & 0.04 \\
\hline \multicolumn{3}{|c|}{ Purchase hay/feed-beginning in which month } \\
\hline February & 0.01 & 0.01 \\
\hline March & 0.01 & 0.01 \\
\hline April & 0.01 & 0.01 \\
\hline May & 0.00 & 0.00 \\
\hline June & 0.02 & 0.01 \\
\hline July & 0.06 & 0.02 \\
\hline August & 0.03 & 0.01 \\
\hline September & 0.06 & 0.02 \\
\hline October & 0.06 & 0.02 \\
\hline November & 0.04 & 0.02 \\
\hline December & 0.02 & 0.01 \\
\hline Missing or Not Applicable & 0.68 & 0.04 \\
\hline \multicolumn{3}{|c|}{ Graze fall or winter pastures earlier than planned } \\
\hline No & 0.40 & 0.05 \\
\hline Yes & 0.45 & 0.04 \\
\hline Missing or Not Applicable & 0.16 & 0.04 \\
\hline \multicolumn{3}{|c|}{ Graze earlier than planned-beginning in which month } \\
\hline June & 0.01 & 0.00 \\
\hline July & 0.01 & 0.01 \\
\hline August & 0.06 & 0.01 \\
\hline September & 0.13 & 0.03 \\
\hline October & 0.07 & 0.02 \\
\hline November & 0.02 & 0.01 \\
\hline December & 0.00 & 0.00 \\
\hline Missing or Not Applicable & 0.70 & 0.04 \\
\hline \multicolumn{3}{|c|}{ Destock pastures more than usual } \\
\hline No & 0.43 & 0.05 \\
\hline Yes & 0.44 & 0.05 \\
\hline Missing or Not Applicable & 0.13 & 0.03 \\
\hline \multicolumn{3}{|c|}{ Destock-beginning in which month } \\
\hline April & 0.00 & 0.00 \\
\hline May & 0.02 & 0.01 \\
\hline June & 0.02 & 0.01 \\
\hline July & 0.10 & 0.03 \\
\hline August & 0.08 & 0.02 \\
\hline September & 0.08 & 0.03 \\
\hline October & 0.07 & 0.02 \\
\hline November & 0.01 & 0.00 \\
\hline December & 0.00 & 0.00 \\
\hline Missing or Not Applicable & 0.62 & 0.05 \\
\hline
\end{tabular}


Table 6 (continued)

Weighted proportion

SE

Cull and sell more breeding animals than usual

$\begin{array}{lll}\text { No } & 0.56 & 0.05\end{array}$

$\begin{array}{lll}\text { Yes } & 0.29 & 0.04\end{array}$

Missing or Not Applicable

$0.16 \quad 0.04$

Cull breeding animals-beginning in which month

$\begin{array}{lll}\text { March } & 0.00 & 0.00\end{array}$

$\begin{array}{lll}\text { April } & 0.00 & 0.00\end{array}$

May $\quad 0.01 \quad 0.01$

$\begin{array}{lll}\text { June } & 0.01 & 0.01\end{array}$

$\begin{array}{lll}\text { July } & 0.03 & 0.02\end{array}$

$\begin{array}{lll}\text { August } & 0.03 & 0.02\end{array}$

$\begin{array}{lll}\text { September } & 0.04 & 0.01\end{array}$

$\begin{array}{lll}\text { October } & 0.02\end{array}$

$\begin{array}{lll}\text { November } & 0.02 & 0.00\end{array}$

$\begin{array}{lll}\text { December } & 0.02 & 0.01\end{array}$

$\begin{array}{lll}\text { Missing or Not Applicable } & 0.78 & 0.04\end{array}$

Reporting weighted proportions and standard errors. $N=252$ for all, including missing cases.

\section{Effect of Having a Drought Plan on the Timing of Taking Action}

As described in Haigh et al. (2019), among those who took each type of drought response action in 2016, the timing of beginning to act varied from early summer to late fall. Purchases of supplemental feed began most frequently in July 2016, but many waited until September or October to begin making these purchases. Early grazing of fall/ winter pastures began most frequently in September, only a month or two earlier than normal in some cases. Most destocking (through any means) began July through October, while the culling of the breeding herd was most likely to begin in October.

Having a drought plan did not directly predict the timing of destocking or any of the other drought response actions in 2016 (Table 8). While having a drought plan had no significant direct effect on timing, the use of the rancher's own assessment of conditions was associated with earlier start dates of destocking and culling the breeding herd. Given the influence of having a drought plan on the use and influence of the rancher's own assessment of conditions, the effect of having a drought plan may be primarily an indirect one. 


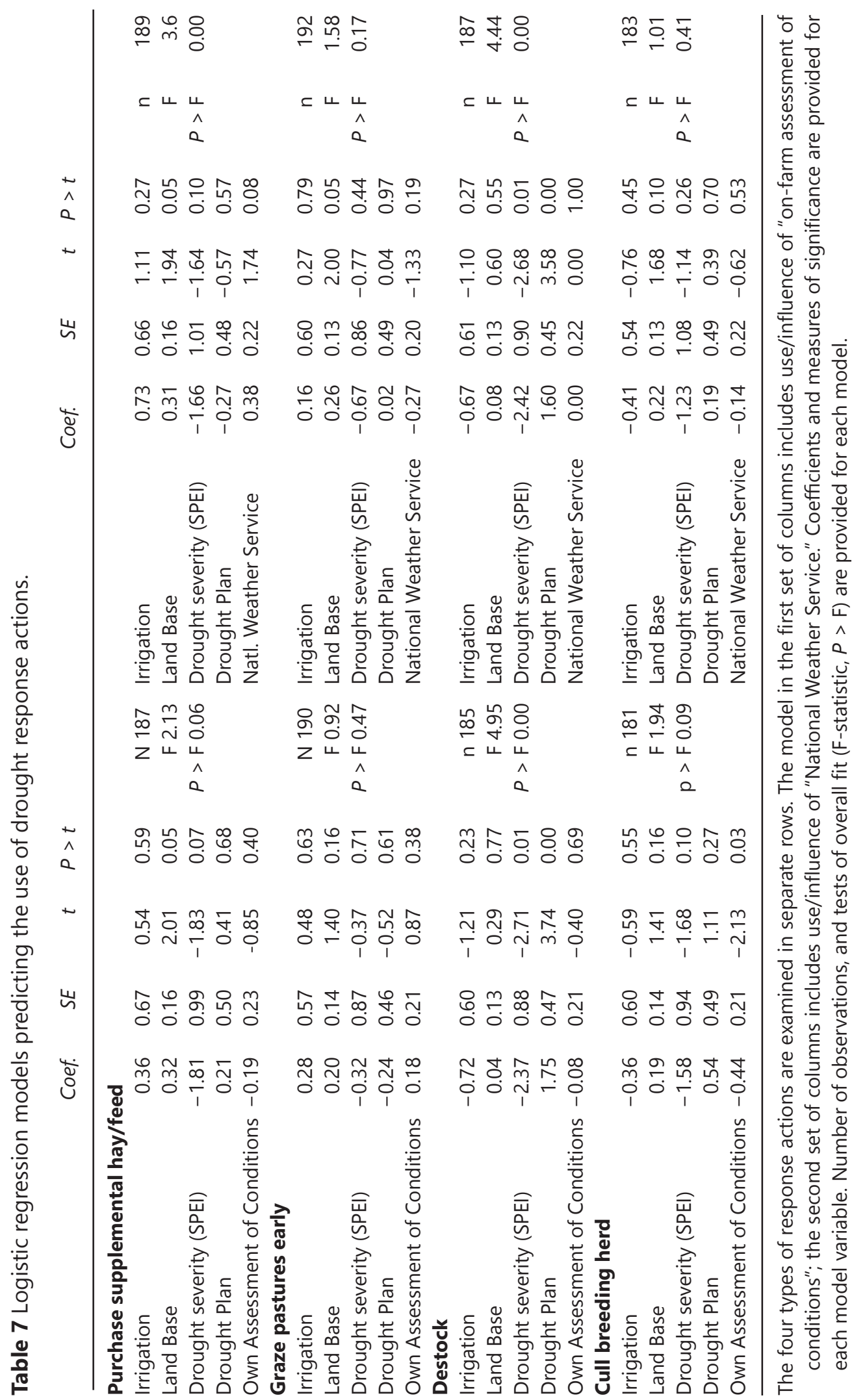




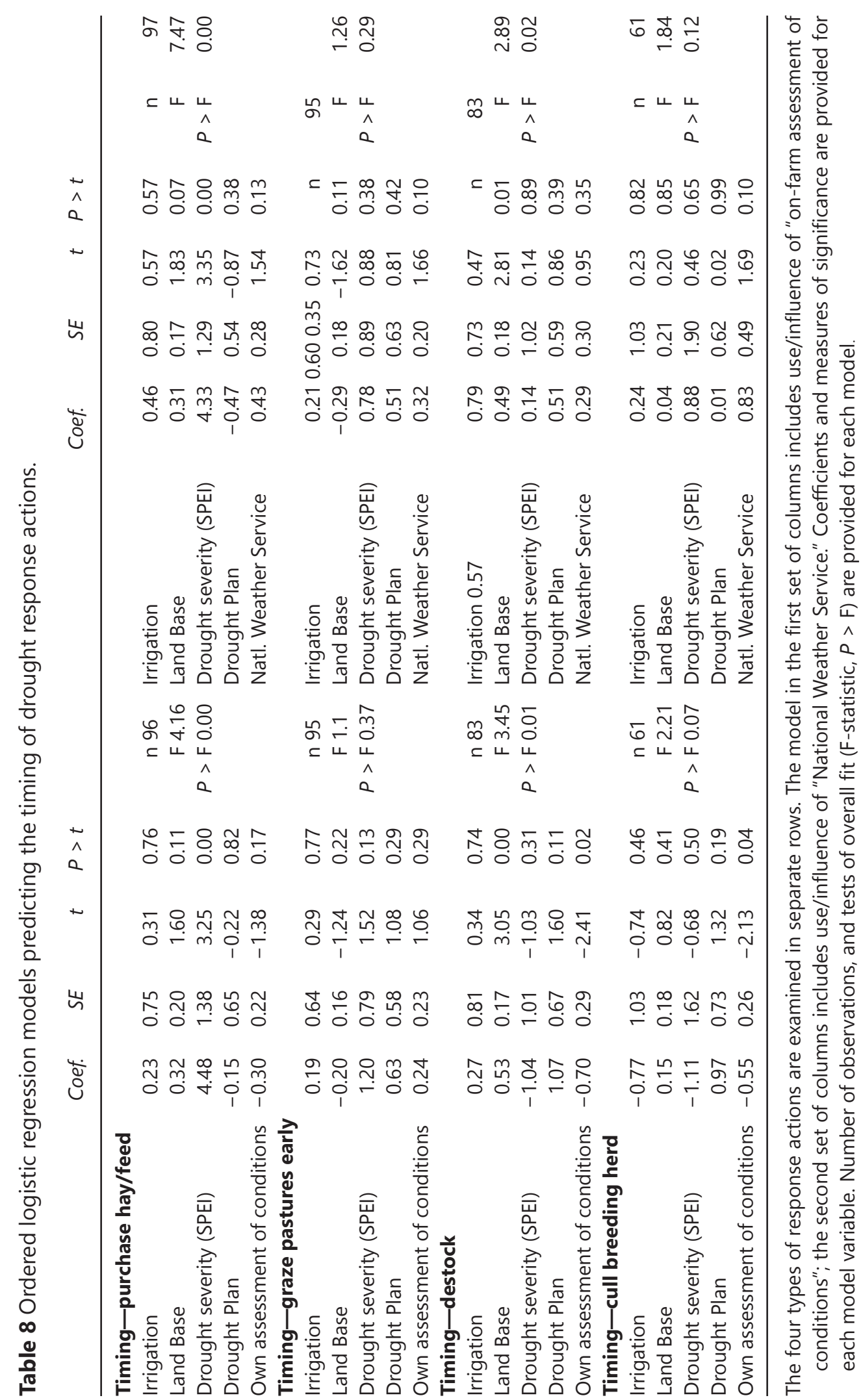




\section{Discussion}

We introduced this study by noting that the resources available to range-based livestock producers for drought management can be scarce. Resources such as land, income, education and experience have been shown to be critical sources of capacity that land managers use to adapt to and cope with climate stresses such as drought (Engle 2011; Kachergis et al. 2104). The rancher's adaptive capacity helps to determine the ranch system's vulnerability to climate risk or its resilience to disturbances by shaping how they manage ranch resources during drought (Folke 2006). The Protective Action Decision Model acknowledges the influence of adaptive capacity on decision making, though not explicitly, as "receiver characteristics" and "situational impediments and facilitators" (Lindell and Perry 2012). This study provides evidence that having a drought contingency plan is an additional source of adaptive capacity, by demonstrating how the plan influences the protective action decision process.

Our first research question helps us understand the degree that having a drought plan is related to other sources of adaptive capacity, commonly thought to include resources like education, experience, natural resources, and income (Yohe and Tol 2002; Smit and Wandell 2006; Tinch et al. 2015). We found that ranchers managing larger areas of land and with larger gross sales are more likely than those managing smaller operations to have plans for drought. But the effect of having a drought plan on drought response was not attributable to the fact that ranchers with larger-sized operations are more likely to have them. This finding makes clear that having a drought plan, as a source of adaptive capacity, functions independently from other ranch resources such as land or finances.

So how does a plan function as a source of adaptive capacity? We found that having a plan appears to indirectly affect the rancher's ability to identify an approaching threat and directly affect his or her ability to identify actionable responses to the threat, framed in terms of the Protective Action Decision Model process. As a result, ranchers with a drought plan were more likely to destock pastures more than usual through culling, early weaning, ending grazing contracts, sending to feedlot, etc., compared with those without a plan, even controlling for drought severity and size of operation. The fact that this 
specific action was related to the drought plan while other actions were not provides validity to the study. We know from past investigations that decisions around destocking are at the core of many documented drought plans (Knutson and Haigh, 2013). Destocking pastures is recommended as a preferred drought management strategy, as opposed trying to "feed through a drought" with purchased supplemental feed (Haigh and Knutson 2013). But for many ranchers, the decision to destock may be more difficult and fraught than a decision to purchase feed, because of the potential costs and risks associated with destocking (Shrum et al. 2018; Haigh et al., 2012 in review). Thus, a plan that specifies when and how to destock may help a rancher overcome uncertainty in choosing this strategy as a drought response.

The Protective Action Decision Model suggests that situational uncertainty can cause decision makers to cycle repeatedly through decision-making stages, leading to reactive versus proactive response (Lindell and Perry 2012). Insofar as having a plan decreases uncertainty and the propensity to wait to act, it may be considered a source of adaptive capacity. While having a plan did not have significant direct effects on the timing of drought response in this study, it appears to have had an indirect effect by increasing ranchers' on-farm monitoring of drought conditions, which itself predicts earlier initiation of destocking. Having a drought plan also increased ranchers' use of one source of scientific drought monitoring information (National Weather Service). This study affirms Webb and Sheeran's (2007) assertion that having a plan increases the decision maker's ability to detect cues to action. With a plan that defines the connection between drought monitoring cues (if-condition) and specific actions (then-action), the rancher may better understand the salience and fit of monitoring and early warning to their decision spaces and, thus, be more likely to use available resources in decision making during drought.

In other words, the drought plan may help tie monitoring information more explicitly to the decision makers' processes of initiating behaviors related to drought response. As ambiguity is one cause of decision makers' delaying protective action (Lindell and Perry 2012), the drought plan's indirect effect may have been to increase their acuity to environmental conditions and sense of certainty that what they were seeing should trigger action earlier than later. In this way, having a plan strengthens the connection between drought early warning and 
drought preparedness, mitigation, and response, two of the key pillars of drought management recognized by the International Drought Management Programme (IDMP). ${ }^{7}$

In this study, the drought contingency plan is defined skeletally as having an if-component and a then-component, but we are aware that there are likely to be large differences among ranchers in the form of their plan, as well as the quality of their plan. We suggest that the quality of the plan may be judged on the degree to which it successfully translates a situation of uncertainty into opportunities for decisive and beneficial actions. While all of the ranchers in this study were faced with the same situation of uncertainty, some took decisive action at points in the year that may have saved forage and range health. Haigh et al. (2019) found that earlier timing of destocking was associated with less overall harm to range productivity, as reported by survey respondents. .

The lack of direct association having a drought plan and the timing of destocking in this study may indicate that the ranchers' drought plans do not uniformly have decisive triggers tied to precipitation and forage production months. On the other hand, decisive and timely destocking was associated with on-farm monitoring. This suggests that it is not enough for ranchers to have a plan that general drought conditions will trigger a specific action; rather, it is important for those with a plan to actively monitor conditions at key points in the growing season to determine whether their trigger for taking action has been reached. This finding supports past research with ranchers who say that on-farm monitoring is one of the most critical aspects of their plan, regardless of the form of the plan, either written or remembered, based on traditional or scientific knowledge (Haigh and Knutson 2013).

While this study focused on the 2016 drought yr, some parts of the study area (particularly northwest South Dakota) experienced moderate to extreme drought again the following yr (2017). While there was no statistically significant difference in intra-annual timing of destocking based on having a plan or not, those who destocked at any point in 2016 may have seen benefits to their action during the subsequent

7 https://public.wmo.int/en/programmes/ integrated-drought-management-programme 
drought yr of 2017. This speculation highlights a limitation of the study design. The study focused on the impacts of the first year of drought, and data were collected during the winter months directly following the drought. While operations may have sufficient buffers in forage or other feed supplies to withstand a 1-yr drought, the second $\mathrm{yr}$ of drought is likely to pose greater challenges. It is possible that ranchers with a drought plan, having been more likely to destock in 2016 than those without a plan, may have experienced the 2017 drought differently. But that is conjectural for this study and suggests the need for follow-up and longitudinal research on drought management and impacts in the future.

This study contributes to theoretical literature by finding evidence that the implementation intention in the form of a drought contingency plan has indirect and direct effects on the protective action decision process, but it can only suggest possible causal pathways to be examined in future studies. We suggest first that having a contingency plan appears to have some effect on the decision maker's process of assessing whether a threat is severe enough to take action. Second, by specifying in advance which activities are to be taken, having a plan appears to influence the PADM process of assessing and selecting response options. There is a great deal of room to explore these relationships further, as well as other potential effects of contingency planning on protective action decision making.

The findings of this study should be considered exploratory. The study sample appears to be representative of the target population; however, the overall sample size is not large. Further, because only a subset of the sample undertook various drought response actions, statistical analysis of the timing of those actions could only be done with even smaller numbers of respondents. As noted in the methods section, in the examination of the timing of drought response actions, our analysis was only powerful enough to detect medium effect sizes (e.g., 0.30 and above) and may have missed smaller effect size relationships. Future research designed to obtain larger cross-sectional, probability-based samples may elucidate important, though more subtle, relationships between drought planning and drought response. 


\section{Implications}

According to Marshall and Smajgl (2013), helping resource managers move from very low to even moderate levels of adaptive capacity is challenging, but we find that it may be possible to increase adaptive capacity through targeted opportunities to plan for climate hazards. The National Drought Mitigation Center's Managing Drought Risk on the Ranch guide ${ }^{8}$ provides assistance in setting situationally appropriate triggers and response plans. Resources such as this should be useful to ranchers and range advisors as a tool to improve adaptive capacity for ranchers in any ranch context. We find that the process of developing understanding about key precipitation months, forage production, and optimal decision times may be a particularly beneficial part of the planning process. Developers of climate information tools can help facilitate this process by more intentionally connecting their tools with specific decision points. The development of cropspecific decision calendars is an increasingly used approach for improving linkages between the timing of decisions and the timing of conditions (Takle et al. 2014; Haigh et al. 2015; Ray and Webb 2016). Studies such as this (and Haigh et al. 2019) that link climate conditions, decisions and the timing of decisions, and the impacts or outcomes of a climate event have value for the development of decision calendars and improved usability of climate information in ranch decision making.

Overall, we find support for integration of implementation intentions into models of protective action behavior such as the Protective Action Decision Model. Consideration of preset if-then plans may improve understanding of how to communicate risk and early warning information in ways that are actionable by decision makers. Contingency plans are unlikely to be a silver bullet but show potential for improving the outcomes of hazard response for natural resource managers. While drought planning is mostly practiced by rangelandbased livestock producers and is less common among other types of agricultural producers, future efforts to increase the use and usability of climate information for the entire agricultural sector may benefit from considering how the development of appropriate if-then plans 
affect both the timing of decision making and the use of information in decision making. As such, this study demonstrates again the relevance of social theory literatures to improving rangeland management and drought mitigation and response.

$$
\ddagger \ddagger \ddagger \neq \ddagger
$$

Competing Interests The authors declare that they have no known competing financial interests or personal relationships that could have appeared to influence the work reported in this paper.

Acknowledgments The authors are grateful to the agricultural producers and advisors who pretested the survey and to the producers who participated in the survey. The authors are also grateful to Deborah Wood for proofreading assistance and Chris Poulsen for map design assistance. Errors remain the authors' own.

Funding This work was supported by the National Oceanic and Atmospheric Administration Sectoral Application Research Program via grants NA160AR4310131 and NA16OAR4310130, and by the National Integrated Drought Information System.

\section{References}

Aarts, H., Dijksterhuis, A., Midden, C., 2002. To plan or not to plan? Goal achievement or interrupting the performance of mundane behaviors. European Journal of Social Psychology 29, 971-979.

American Association for Public Opinion Research, 2015. Standard definitions: final dispositions of case codes and outcome rates for surveys, 8 th ed. Online https://www.aapor.org/Standards-Ethics/Standard-Definitions-(1).aspx Accessed July 1, 2020.

Becker, J.S., Paton, D., Johnston, D.M., Ronan, K.R., 2013. Salient beliefs about earthquake hazards and household preparedness. Risk Analysis 33, 1710-1727.

Bedell, T., Ganskopp, D., 1980. Rangelands in dry years: drought effects on range, cattle, and management. Pacific Northwest Cooperative Extension Publication 200.

Brasseur, G.P., Gallardo, L., 2016. Earth's future climate services : Lessons learned and future prospects. Earth's Future 79-81.

Briske, D.D., Joyce, L.A., Polley, H.W., Brown, J.R., Wolter, K., Morgan, J.A., Mc- Carl, B.A., ... Bailey, D.W., 2015. Climate-change adaptation on rangelands: linking regional exposure with diverse adaptive capacity. Frontiers in Ecology and the Environment. Online https://doi.org/10.1890/140266 
Brunson, M.W., Huntsinger, L., 2008. Ranching as a conservation strategy: can old ranchers save the new West. Rangeland Ecology \& Management 61, 137-147.

Cash, D., Clark, W., Alcock, F., Eckley, N., Jäger, J., 2002. Salience, credibility, legitimacy and boundaries: linking research assessment and decision making (RWP02- 046). Faculty Research Working Papers. Cohen, J., 1992. A power primer. Quantitative Methods in Psychology 112, 155-159.

Coppock, D.L., 2011. Ranching and multiyear droughts in Utah: production impacts, risk perceptions, and changes in preparedness. Rangeland Ecology \& Management 64, 607-618.

Derner, J., Briske, D., Reeves, M., Brown-Brandl, T., Meehan, M., Blumenthal, D., Travis, W., Augustine, D., Wilmer, H., Scasta, D., Hendrickson, J., Volesky, J., Edwards, L., Peck, D., 2018. Vulnerability of grazing and confined livestock in the Northern Great Plains to projected mid- and late-twenty-first century climate. Climate Change 146, 19-32.

Derner, J.D., Augustine, D.J., 2016. Adaptive management for drought on rangelands. Rangelands 38, 211-215.

Dillman, D., 1991. The design and administration of mail surveys. Annual Review of Sociology 17, 225-249.

Dillman, D.A., Smyth, J.D., Christian, L.M., 2014. Internet, phone, mail, and mixedmode surveys: the tailored design method. John Wiley \& Sons, Hoboken, NJ.

Dunn, B., Smart, A., Gates, R., 2005. Barriers to successful drought management: why do some ranchers fail to take action. Rangelands 27, 13-16.

Engle, N.L., 2011. Adaptive capacity and its assessment. Global Environmental Change 21, 647-656.

Folke, C., 2006. Resilience: the emergence of a perspective for social-ecological systems analysis. Global Environmental Change 16 (3), 253-267.

Gollwitzer, P.M., Sheeran, P., 2006. Implementation intentions and goal achievement: A meta-analysis of effects and processes. Advances in Experimental Social Psychology 38, 69-119.

Grothmann, T., Patt, A., 2005. Adaptive capacity and human cognition: the process of individual adaptation to climate change. Global Environmental Change 15, 199-213.

Haigh, T., Knutson, C., 2013. Roles of perceived control and planning in ranch drought preparedness. Great Plains Research 23, 51-58.

Haigh, T., Takle, E., Andresen, J., Widhalm, M., Carlton, J.S., Angel, J., 2015. Mapping the decision points and climate information use of agricultural producers across the US Corn Belt. Climate Risk Management 7, 20-30.

Haigh, T., Koundinya, V., Hart, C., Klink, J., Lemos, M., Mase, A.S., Prokopy, L., Singh, A., Todey, D., Widhalm, M., 2018. Provision of climate services for agriculture: public and private pathways to farm-decision making. Bulletin of the American Meteorology Society 99 (9), 1781-1790. 
Haigh, T.R., Schacht, W., Knutson, C.L., Smart, A.J., Volesky, J., Allen, C., Hayes, M., Burbach, M., 2019. Socioecological determinants of drought impacts and coping strategies for ranching operations in the Great Plains. Rangeland Ecology \& Management 72, 561-571.

Haigh, T., Schacht, W., Knutson, C.L., Smart, A.J., Volesky, J., Allen, C., Hayes, M., Burbach, M., 2012. Preparing for drought on the ranch: lessons from 2012. Research Counts 3 (6) In review. https://hazards.colorado.edu/news/ research-counts/preparing-for-drought-on-the-ranch-lessons-from-2012

Hosmer, D.W., Lemeshow, S., Sturdivant, R.X., 2013. Applied logistic regression. John Wiley \& Sons., Hoboken, NJ. USA, p. 511.

Jianjun, J., Yiwei, G., Xiaomin, W., Nam, P.K., 2015. Farmers' risk preferences and their climate change adaptation strategies in the Yongqiao District, China. Land Use Policy 47, 365-372.

Joyce, L.A., Briske, D.D., Brown, J.R., Polley, H.W., McCarl, B.A., Bailey, D.W., 2013. Climate change and North American rangelands: assessment of mitigation and adaptation strategies. Rangeland Ecology \& Management 66, 512-528.

Kachergis, E., Derner, J.D., Cutts, B.B., Roche, L.M., Eviner, V.T., Lubell, M.N., Tate, K.W., 2014. Increasing flexibility in rangeland management during drought. Ecosphere 5, 1-14.

Kirchhoff, C.J., Carmen Lemos, M., Dessai, S., 2013. Actionable knowledge for environmental decision making: broadening the usability of climate science. Annual Review of Environmental Resources 38, 393-414.

Knutson, C., Haigh, T., 2013. A drought-planning methodology for ranchers in the great plains. Rangelands 35, 27-33.

Knutson, C., Fuchs, B., 2016. New tools for assessing drought conditions for rangeland management. Rangelands 38, 177-182.

Kuligowski, E., 2013. Predicting human behavior during fires. Fire Technology 49, 101-120.

Lemos, M.C., Kirchhoff, C.J., Ramprasad, V., 2012. Narrowing the climate information usability gap. Nature and Climate Change 2, 789-794.

Lindell, M.K., Perry, R.W., 2012. The Protective Action Decision Model: theoretical modifications and additional evidence. Risk Analysis 32, 616-632.

Marshall, N.A., Gordon, I.J., Ash, A.J., 2011. The reluctance of resource-users to adopt seasonal climate forecasts to enhance resilience to climate variability on the rangelands. Climate Change 107, 511-529.

Marshall, N.A., Smajgl, A., 2013. Understanding variability in adaptive capacity on rangelands. Rangeland Ecology \& Management 66 (1), 88-94.

McCaffrey, S., Wilson, R., Konar, A., 2018. Should I stay or should I go now? Or should I wait and see? Influences on wildfire evacuation decisions. Risk Analysis 38, 1390-1404.

McClaran, M.P., Butler, G.J., Wei, H., Ruyle, G.D., 2015. Increased preparation for drought among livestock producers reliant on rain-fed forage. Natural Hazards 79, 151-170. 
Mortreaux, C., ... Barnett, J., 2017. Adaptive capacity: exploring the research frontier, 8. Wiley Interdisciplinary Review of Climate Change. Online https://doi. org/10.1002/wcc.467

National Oceanic and Atmospheric Administration Climate Projection Center, undated, 2020. Drought Outlook Verification. Online https://origin.cpc.ncep. noaa.gov/products/expert assessment/SDO/sdo verification/2012/AMJ12.png Accessed July 21, 2020.

Otkin, J., Haigh, T., Mucia, A., Anderson, M.C., Hain, C., 2018. Comparison of agricultural stakeholder survey results and drought monitoring datasets during the 2016 U.S. Northern Plains flash drought. Weather Climate Society 10, 867-883.

Parsons, J., 1996. Estimating the Coverage of Farm Service Agency Crop Acreage Totals SRB Research Report SRB-96-02 U.S. Department of Agriculture

National Agricultural Statistics Service. Online https://www.nass.usda.gov/ Education and Outreach/Reports, Presentations and Conferences/Survey Reports/Estimating\%20the\%20Coverage\%20of\%20Farm\%20Service\%20 Agency\%20Crop\%20Acreage\%20Totals.pdf Accessed July 1, 2020.

Patterson, H.H., Richardson, C., 2007. Utilizing the balanced scorecard in ranch management: cattle production systems perspective. In: Rangelands 22-27.

Peck, D., Derner, J., Parton, W., Hartman, M., Fuchs, B., 2019. Flexible stocking with Grass-Cast: a new grassland productivity forecast to translate climate outlooks for ranchers. Western Economy Forum 17, 24-39.

Pendergrass, A.G., Meehl, G.A., Pulwarty, R., Hobbins, M., Hoell, A., AghaKouchak, A., Bonfils, C.J., Gallant, E.A.J., Hoerling, M., Hoffmann, D., Kaatz, L., Lehner, F., Llewellyn, D., Mote, P., Neale, R.B., Overpeck, J.T., Sheffield, A., Stahl, K., Svoboda, M., Wheeler, M.C., Wood, A.W., ... Woodhouse, C.A., 2020. Flash droughts present a new challenge for subseasonal-to-seasonal prediction. Nature Climate Change. Online https://doi.org/10.1038/s41558-0200709-0

Ray, A.J., Webb, R.S., 2016. Understanding the user context: decision calendars as frameworks for linking climate to policy, planning, and decision-making. In:

Parris, A.S., Garfin, G.M., Dow, K., Meyer, R., Close, S.L. (Eds.), Climate in context: science and society partnering for adaptation. John Wiley \& Sons, West Sussex, UK, pp. 27-50.

Roche, L.M., Schohr, T.K., Derner, J.D., Lubell, M.N., Cutts, B.B., Kachergis, E., Eviner, V.T., Tate, K.W., 2015. Sustaining working rangelands: insights from rancher decision making. Rangeland Ecology \& Management 68, 383-389.

Roche, L.M., 2016. Adaptive rangeland decision-making and coping with drought. Sustainability 8. Online https://doi.org/10.3390/su8121334

Sayre, N.F., Carlisle, L., Huntsinger, L., Fisher, G., ... Shattuck, A., 2012. The role of rangelands in diversified farming systems: Innovations, obstacles, and opportunities in the USA. Ecology Society 17. Online https://doi.org/10.5751/ ES-04790-170443 
Sayre, N.F., McAllister, R.R., Bestelmeyer, B.T., Moritz, M., Turner, M.D., 2013. Earth stewardship of rangelands: coping with ecological, economic, and political marginality. Frontiers in Ecology and the Environment 11, 348-354.

Shrum, T.R., Travis, W.R., Williams, T.M., ... Lih, E., 2018. Managing climate risks on the ranch with limited drought information. Climate Risk Management. Online https://doi.org/10.1016/j.crm.2018.01.002

Smart, A.J., Dunn, B.H., Johnson, P.S., Xu, L., Gates, R.N., 2007. Using weather data to explain herbage yield on three Great Plains plant communities. Rangeland Ecology \& Management 60, 146-153.

Smart, A.J., Harmoney, K., Scasta, J.D., Stephenson, M.B., Volesky, J.D., Vermeire, L.T., Mosley, J.C., Sedivec, K., Meehan, M., Haigh, T., Derner, J.D., McClaran, M.P., 2019. Critical decision dates for drought management in Central and Northern Great Plains rangelands. Rangeland Ecology \& Management https://doi. org/10.1016/j.rama.2019.09.005

Smit, B., Skinner, M.W., 2002. Adaptation options in agriculture to climate change: a typology. Mitigation Adaptation Strategies for Global Change 7, 85-114.

Smit, B., Wandel, J., 2006. Adaptation, adaptive capacity and vulnerability. Global Environmental Change 16, 282-292.

Statacorps, L. P. 2009. Stata statistical software. College Station, TX: StataCorp LLC.

Takle, E.S., Anderson, C.J., Andresen, J., Angel, J., Elmore, R.W., Gramig, B.M., Guinan, P., Hilberg, S., Kluck, D., Massey, R., Niyogi, D., 2014. Climate forecasts for corn producer decision making. Earth Interactions 18 (5), 1-8.

Terpstra, T., Lindell, M.K., 2013. Citizens' perceptions of flood hazard adjustments: an application of the Protective Action Decision Model. Environmental Behavior 45, 993-1018.

Thurow, T.L., Taylor, C.A., 1999. Viewpoint: the role of drought in range management. Journal of Range Management 52, 413-419.

Tinch, R., Jäger, J., Omann, I., Harrison, P.A., Wesely, J., Dunford, R., 2015. Applying a capitals framework to measuring coping and adaptive capacity in integrated assessment models. Climate Change 128, 323-337.

US Department of Agriculture Economic Research Service. undated. Farming and Farm Income. Online https://www.ers.usda.gov/data-products/ag-and-foodstatistics-charting-the-essentials/farming-and-farm-income/ Accessed July 21, 2020.

US Department of Agriculture Natural Resources Conservation Service, 2012. NRCS and Partner Outreach Segments on Dakota Farm Talk Radio Program. Drought management (July 2012) Online https://www.nrcs.usda.gov/wps/ portal/nrcs/main/sd/newsroom/features/

Webb, T.L., Sheeran, P., 2008. Mechanisms of implementation intention effects: the role of goal intentions, self-efficacy, and accessibility of plan components. Brtitish Journal Society of Psychology 47, 373-395. 
Webb, T.L., Sheeran, P., 2007. How do implementation intentions promote goal attainment? A test of component processes. Journal of Experimental Social Psychology 43, 295-302.

Wilhite, D.A., Svoboda, M.D., 200 0. Drought early warning systems in the context of drought preparedness and mitigation. In: Early warning systems for drought preparedness and drought management, Proceedings of an Expert Group Meeting held in Lisbon, Portugal, 5-7 September 2000, pp. 1-21, Wilhite, D. A., Sivakumar, M. V. K. and Wood, D. A. [eds.]. Geneva, Switzerland: World Meteorological Organization.

Yohe, G., Tol, R.S.J., 2002. Indicators for social and economic coping capacitymoving toward a working definition of adaptive capacity. Global Environmental Change $12,25-40$. 